\title{
Patryk Gacka
}

Uniwersytet Warszawski

\section{'NULLUM CRIMEN, NULLA POENA SINE LEGE' A ZBRODNIE MIĘDZYNARODOWE*}

\section{ZASADA LEGALIZMU - OD IDEALIZACJI DO DOMNIEMANIA}

Zasada nullum crimen, nulla poena sine lege, nazywana także zasadą legalizmu karnego, ma niewątpliwie charakter idealizacyjny. Określając materialne i formalne kryteria służące zagwarantowaniu możliwości poznania treści komunikatu kryminalizacyjnego przez jego adresata, symbolizuje ona pożądany kształt prawa karnego jako specyficznego medium komunikacyjnego pomiędzy twórcą a adresatem norm karnoprawnych.

Zamysł leżący u podstaw zasady legalizmu bywa jednak niekiedy nazywany - w bardziej krytycznym i realistycznym zarazem ujęciu „utopią legalizmu”: „[...] jesteśmy kuszeni do wyobrażania sobie utopii legalizmu, w której wszystkie normy pozostają całkowicie jasne, spójne ze sobą, znane każdemu obywatelowi oraz nigdy niedziałające wstecz"1.

Wymóg obowiązywania zakazu w chwili podejmowania określonej aktywności, jak i skutecznego informowania o jego treści jest nie tylko idealizacją, w praktyce jest on bowiem także domniemywany.

* Finansowane ze środków stypendium doktorskiego z Narodowego Centrum Nauki (2019/32/T/HS5/00563).

1 L. Fuller, The Morality of Law, New Haven 1969, s. 41. 
Wprowadzenie w życie zakazu karnego w zgodzie z obowiązującym modelem procedury legislacyjnej (krajowej czy międzynarodowej), a następnie jego ogłoszenie w publicznie dostępnym publikatorze (o ile taki istnieje) świadczyć ma o tym, że jednostkowy adresat zakazu karnego posiada wiedzę o nim, a zatem może postępować zgodnie z obowiązującym standardem, oczywiście jeżeli zależy mu na tym, ażeby danej normy przestrzegać. W złożonej, otaczającej nas rzeczywistości normatywnej jest to jednak domniemanie idące tak daleko, że ociera się ono wręcz o jawny zarzut kontrfaktyczności. Ignorancja prawna, niebędąca w rzeczywistości ignorancją w pełnym tego słowa znaczeniu, lecz raczej intelektualną niemożnością poznania treści wszystkich aktów prawnych, w tym także zawartych w nich zakazów karnych, dotyka bowiem w mniejszym lub większym zakresie każdego człowieka.

Przyczyn tej pozornej i, jak się zdaje, narastającej ,ignorancji” jest z pewnością wiele. Komunikaty kryminalizacyjne docierają do nas współcześnie z różnych stron, w różnej postaci oraz ze zróżnicowaną, zwykle jednak zbyt dużą częstotliwością. Pierwszy wymiar tej swoistej multicentryczności kryminalizacyjnej jest oczywisty - normy karnoprawne tworzy się obecnie nie tylko na płaszczyźnie krajowej; prawo karne podlega stopniowej internacjonalizacji, w rezultacie czego człowiek mimowolnie staje się adresatem norm nie tylko własnego państwa (łącznik obywatelstwa), lecz także miejsca przebywania (łącznik terytorialny), prawa innych państw (łącznik ochronny i łącznik ofiary), w końcu zaś coraz liczniejszych regulacji międzynarodowych (łącznik uniwersalny, łącznik międzynarodowy). To głęboko zawarte w zasadzie legalizmu domniemanie nie tyle znajomości, ile możliwości poznania treści norm karnoprawnych w odniesieniu do mieszkańców danego państwa, w zasadzie niknie w zestawieniu z jeszcze bardziej idealizacyjnym domniemaniem odnośnie do obywateli innych państw, którzy z racji wspomnianych powyżej modeli jurysdykcyjnych, jak i nasilających się zjawisk migracji powinni często postępować zgodnie z przepisami więcej aniżeli jednego tylko systemu prawnego. Każdy zaś człowiek na świecie jest zobowiązany do tego, by znać zakazy wynikające z międzynarodowego prawa karnego i przestrzegać ich, niezależnie od tego, czy 
państwo jego pochodzenia normy te akceptuje (ius cogens) i zamierza wykonywać (ratyfikacja, transpozycja) na swoim własnym terytorium.

Komunikaty kryminalizacyjne docierają więc do nas zewsząd, wiążą nas w tym samym czasie i wszystkie są - co do zasady - równie akceptowalne z perspektywy gwarancyjnie zorientowanej zasady legalizmu. Gdyby tego było mało, decyzje kryminalizacyjne przestają być aktywnościami podejmowanymi z przysłowiową „otwartą przyłbicą”; są natomiast markowane w innych aktach prawnych jako przepisy końcowe albo w drodze jednoustawowych zmian różnych aktów prawnych, w tym i tych zawierających przepisy karne, co dodatkowo utrudnia identyfikację zachodzących w ciągłym trybie zmian legislacyjnych. Powszechne staje się także przyjmowanie rozwiązań hybrydowych na styku poszczególnych gałęzi prawnych (np. prawa karnego i administracyjnego), w wyniku czego stajemy się adresatami norm quasi-karnych. Ten rozrost normatywny nie jest jednak przypadkowy. Mechanizmy karnoprawne są w dzisiejszych czasach postrzegane wielozadaniowo, a więc nie tylko jako instrumenty służące ochronie pewnych wartości ludzkich, lecz także zabezpieczeniu interesów własnych nowoczesnego państwa administracyjnego ${ }^{2}$.

W tej złożonej rzeczywistości normatywnej zasada legalizmu - podstawowy zwornik gwarancyjny przed podleganiem odpowiedzialności karnej za zachowanie, którego negatywnej oceny nie sposób było rozpoznać - zdaje się obecnie bardziej niż kiedykolwiek oparta na wieloaspektowej fikcji, dodatkowo umacnianej niekończącą się aktywnością legislacyjną, która prowadzi do stanu „nadkryminalizacji”

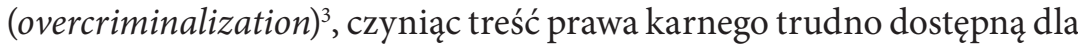
profesjonalistów, o innych członkach społeczeństwa nie wspominając. Znamienne są w tej mierze słowa Johna Gardnera, który dobitnie stwierdził: „A więc nawet ja, posiadający wykształcenie prawnicze, jestem w coraz wyższym stopniu narażony na wciągnięcie ni stąd, ni zowąd w zasadzkę przez normy prawne. Ten potencjał do tworzenia zasadzek

2 Por. V. Chino, Criminal Law in the Age of the Administrative State, Oxford 2018; M. Thorburn, Criminal law as public law, [w:] Philosophical Foundations of Criminal Law, eds. A. Duff, S.P. Green, Oxford 2011, s. 21-43.

3 D. Husak, Overcriminalization. The Limits of the Criminal Law, Oxford 2008. 
czyni prawo marnym przewodnikiem dla tych, którzy starają się postępować zgodnie z nim, stając się przekleństwem zasady rządów prawa"4.

Do tego dochodzi jeszcze coraz istotniejszy wymiar ponadnarodowy. Wiążą nas normy karne zawarte w różnych źródłach prawa międzynarodowego, stanowione i interpretowane na różnych poziomach i w różnych uwarunkowaniach geograficznych (lokalne, regionalne, globalne). Niektóre $\mathrm{z}$ nich mogą być stosowane bezpośrednio, inne wymagają przeniesienia na poziom krajowy; jedne są spisane, inne - chociażby międzynarodowe prawo zwyczajowe - mają ze swej istoty charakter lex non scripta. Kluczowa jest także dynamika ich wykładni przeprowadzanej często nie w krajowym, lecz właśnie w międzynarodowym obiegu instytucjonalnym. Wszystko to tworzy obraz specyficznej relacji pomiędzy jednostką a konglomeratem norm karnoprawnych; obraz, w którym przeobrażeniu podlega założenie o możliwości poznania i kierowania własnym zachowaniem zgodnie z treścią norm w kolejną konstrukcję intelektualną potrzebną do legitymizacji istniejącego systemu, która nie ma jednak zbyt wiele wspólnego z rzeczywistością.

Nie oznacza to jednak, że ten trudny do pogodzenia konflikt krajowej i międzynarodowej praktyki legislacyjnej z gwarancyjnym, idealistycznym ujęciem zasady legalizmu musi koniecznie prowadzić do negatywnych dla jednostki skutków. Konflikt ten może być bowiem na różne sposoby łagodzony. Jeden z nich, sięgający teorii kryminalizacji, wyraża się w związkach prawa karnego i moralności, która jako zbiór imperatywów może stanowić autonomiczne źródło informacji o tym, które zachowania są zakazane (tj. niemoralne), a które nie. W tym też sensie można powiedzieć, że nauka o moralności powinna wspierać przewidywalność negatywnej oceny danego zachowania karalnego ${ }^{5}$. Aby jednak cel ten został osiągnięty, prawo karne musi wpierw posiadać treść związki te potwierdzającą. Tak rozumiana perspektywa etyczna nie będzie przy tym pozwalała na wywiedzenie granic kryminalizacji w ob-

\footnotetext{
4 J. GARDner, The Twilight of Legality, «Australasian Journal of Legal Philosophy» 43/2018, s. 3.

K. Szczucki, Dostępność moralna czy językowa? Rzecz o wykładni prokonstytucyjnej prawa karnego, [w:] 'Nullum crimen sine lege', red. I. SEPIoŁo, Warszawa 2012, s. $44 \mathrm{i} \mathrm{n.}$
} 
rębie całego współczesnego systemu prawa karnego. Nie jest to instrument niezawodny także z innego powodu - nie każdy czyn uznawany za niemoralny zasługuje na to, aby podlegać kryminalizacji. W takiej sytuacji, co jasne, niemoralny charakter określonego zachowania nie będzie przydatnym wskaźnikiem jego karalności.

W zakresie, w jakim zbieg zakazów karnych i zakazów moralnych jest jednak możliwy, analiza wymogów dookreślających zasadę legalizmu powinna sprowadzać się do badania nie tylko tekstowej (textual clarity), lecz także - zwłaszcza przy niedostatkach tej pierwszej - moralnej dostępności prawa (moral clarity), wyrażanej przez adekwatne odzwierciedlenie relewantnych norm etycznych na gruncie rozwiązań karnoprawnych ${ }^{6}$. Tak określona dostępność moralna powinna dookreślać standardy wywodzone z zasady legalizmu; zasady, która w zależności od charakteru karalnego zachowania i jego związków z moralnością mogłaby w pewnym sensie fluktuować, nie oferując jednego, uśrednionego standardu gwarancyjnego, a tym samym odpowiadając na problemy i ryzyko związane z wielobiegunowymi praktykami kryminalizacyjnymi. Oznacza to zatem, że tam, gdzie dostępność moralna wspiera przewidywalność karalności, formalne wymogi wywodzone z zasady legalizmu mogłyby przybierać mniej ścisłą postać; tam zaś, gdzie podobnych związków odnotować nie podobna, a dostępność tekstowa jest jedyną płaszczyzną poznania treści normy, próg ten musiałby być odpowiednio wyższy.

W kontekście tego, co zostało już zarysowane powyżej, artykuł ten ma na celu podjęcie problemu moralnej dostępności prawa w zestawieniu ze standardem nullum crimen, nulla poena sine lege możliwym do wywiedzenia z orzecznictwa Europejskiego Trybunału Praw Człowieka oraz pomocniczo także innych sądów i trybunałów w sprawach dotyczących przewidywalności bezprawnego i karalnego charakteru czynów składających się na zbrodnie międzynarodowe. Dwa pytania są w tej mierze szczególnie warte rozważenia. Po pierwsze, do jakiego stopnia karalność tych zbrodni była i jest przewidywalna dla zwykłego

6 Por. J. Gardner, Offences and Defences. Selected Essays in the Philosophy of Criminal Law, Oxford 2007, s. 45. 
adresata normy karnoprawnej? Po drugie zaś, w jakim zakresie uzasadnione jest powoływanie się na wskazany powyżej argument $\mathrm{z}$ „dostępności moralnej” decyzji kryminalizacyjnej w celu zrekompensowania pewnych niedociągnięć formalnych charakterystycznych dla legislacji międzynarodowej?

\section{MięDZynarodowa ZaSAda legalizMu a ŹródŁA ODPOWIEDZIALNOŚCI KARNEJ}

W międzynarodowym prawie praw człowieka zasada legalizmu karnego wyrażona jest między innymi w Konwencji o ochronie praw człowieka i podstawowych wolności (art. 7 EKPC), Międzynarodowym pakcie praw obywatelskich i politycznych (art. 15 MPPOiP) oraz Karcie praw podstawowych Unii Europejskiej (art. $49 \mathrm{KPP})$. W jej świetle odpowiedzialność karna jest dopuszczalna na podstawie dwóch, równoważnych źródeł, tj. prawa wewnętrznego oraz prawa międzynarodowego.

W praktyce podstawą odpowiedzialności karnej w prawie międzynarodowym jest przede wszystkim prawo traktatowe oraz prawo zwyczajowe (art. 7 ust. 1 EKPC, art. 15 ust. 1 MPPOiP, art. 49 ust. 1 KPP) ${ }^{7}$. Ponadto rolę tę pełnić mogą także ogólne zasady prawa uznane przez społeczność międzynarodową (art. 7 ust. 1 oraz 2 EKPC, art. 15 ust. 1 oraz 2 MPPOiP, art. 49 ust. 1 oraz 2 KPP), choć w rzeczywistości przypada im raczej rola subsydiarnego źródła kryminalizacji międzynarodowej wywodzonego metodą identyfikacji pierwiastków spajających

7 Wyrok Wielkiej Izby ETPC z 22 marca 2001 r. w sprawie Streletz, Kessler and Krenz p. Republice Federalnej Niemiec, skargi nr 34044/96, 35532/97 i 44801/98, pkt 90-106; wyrok Wielkiej Izby ETPC z 17 maja 2010 r. w sprawie Kononov p. Łotwie, skarga nr 36376/04, pkt 185-186; wyrok Wielkiej Izby ETPC z 20 października 2015 r. w sprawie Vasiliauskas p. Litwie, skarga nr 35343/05, pkt 171-178. Por. M. DE SAlviA, Compendium de la CEDH: les principes directeurs de la jurisprudence relative à la Convention européenne des droits de l'homme, Strasbourg 2003, s. 390. Odmiennie P. Hofmański, którego zdaniem „brak jest podstaw, aby pod to pojęcie podciągać prawo inne niż traktatowe" - P. Hofmański, Art. 7, [w:] Konwencja o ochronie praw człowieka i podstawowych wolności, I: Komentarz do artykułów 1-18, red. L. GARLICKI, Warszawa 2010, pkt 7 [Legalis]. 
praktykę legislacyjną i orzeczniczą poszczególnych państw, a następnie odpowiednio transponowanego na poziom międzynarodowy w postaci samodzielnej normy karnoprawnej.

Zasada legalizmu stypuluje formalne i materialne wymogi gwarancyjne, których spełnienie ma w założeniu pozwolić adresatowi normy karnoprawnej na poznanie jej treści i postępowanie zgodnie z zawartą w niej dyspozycją. Charakter i liczba tych wymogów nie jest jednak jednolita we wszystkich systemach prawnych i na każdym poziomie regulacji. Opcja maksymalistyczna tej zasady oparta jest na przesłankach lex certa, lex praevia, lex scripta oraz lex stricta. Międzynarodowa zasada legalizmu jest jednak regułą mniej wymagającą, gdyż składa się z trzech, a nie czterech części składowych (lex certa, lex stricta, lex praevia).

\section{3. ŹródŁa PRAWA MIĘDZYNARODOWEGO W ŚWIETLE WYMOGÓW MIĘDZYNARODOWEJ ZASADY LEGALIZMU}

Prawo międzynarodowe nie określa w jednoznaczny sposób tego, co jest, a co nie jest jego źródłem. Podążając jednak za treścią art. 38 ust. 1 Statutu Międzynarodowego Trybunału Sprawiedliwości ${ }^{8}$, dalsze uwagi ograniczać się będą wyłącznie do źródeł podstawowych, tj. umów międzynarodowych i prawa zwyczajowego, oraz zasad prawa uznanych przez społeczność międzynarodową, ponieważ każde z nich może być także źródłem kryminalizacji międzynarodowej. Decyzja państw, aby szeroką i niesprecyzowaną kategorię „prawa międzynarodowego" traktować jako dopuszczalną podstawę odpowiedzialności karnej (art. 7 EKPC, art. 15 MPPOiP, art. $49 \mathrm{KPP})$, świadczy natomiast o tym, że źródła te - zdaniem państw - spełniają in abstracto formalne kryterium zasady legalizmu. Odmienną kwestią jest jednak wypełnienie merytorycznego wymiaru tej zasady. Z tego też względu warto się zastanowić, czy - a jeżeli tak - to pod jakimi warunkami umowa międzynarodowa, zwyczaj międzynarodowy oraz ogólne zasady prawa uznane przez społeczność

\footnotetext{
8 Statut Międzynarodowego Trybunału Sprawiedliwości (Dz. U. z 1947 r. Nr 23, poz. 90).
} 
międzynarodową spełniają kryteria oraz standardy gwarancyjne wynikające z międzynarodowej zasady legalizmu.

\subsection{Nullum CRIMEN SINE LEGE?}

W sprawie Jorgic ETPC stwierdził, że „czyn zabroniony musi być w sposób czytelny zdefiniowany przez prawo. Wymóg ten jest spełniony wtedy, gdy na podstawie warstwy słownej danego przepisu oraz - gdyby zaszła taka potrzeba - z pomocą wykładni sądowej, jednostka jest w stanie określić, czy określone działania lub zachowania doprowadzą do jej odpowiedzialności karnej"".

Dopuszczenie przez międzynarodową zasadę legalizmu odpowiedzialności karnej zarówno na podstawie prawa pisanego (lex scripta), jak i prawa niepisanego (lex non scripta) prowadzi do wniosku, że prawo traktatowe z jednej strony (lex scripta) oraz prawo zwyczajowe i ogólne zasady prawa $\mathrm{z}$ drugiej strony (lex non scripta) zostały uznane za źródła prawa nienaruszające międzynarodowej zasady legalizmu, chyba że w konkretnym przypadku stwierdzone zostanie niespełnienie wymogów określonych przez wspomniane już kryteria lex certa, lex praevia oraz lex stricta.

W świetle niepisanego charakteru norm prawa zwyczajowego oraz ogólnych zasad prawa, prawdopodobieństwo naruszenia wspomnianych płaszczyzn zasady legalizmu - zwłaszcza lex certa oraz lex stricta - zdaje się jednak intuicyjnie wyższe niż w przypadku umów międzynarodowych, choć i te są często formułowane w sposób tak generalny, że wywiedzenie jednoznacznego wzoru postępowania wyłącznie na podstawie analizy językowo-logicznej może być w praktyce bardzo utrudnione ${ }^{10}$.

Lex non scripta, co jasne, nie zawiera przepisów, które mogłyby stanowić podstawę rozpoznania bezprawności (karalności) danego zachowania. Brak stosownego orzecznictwa precyzującego zakres zakazu wywodzonego z niepisanych norm, czego najbardziej wyrazistym przykładem jest okres poprzedzający kazus norymbersko-tokijski,

9 Wyrok ETPC z 12 lipca 2007 r. w sprawie Jorgic p. Republice Federalnej Niemiec, skarga nr 74613/01, pkt 100.

10 N. JAIn, Comparative International Law at the ICTY: The General Principles Experiment, «American Journal of International Law»109.3/2015, s. 488-489. 
i zapoczątkowaną wówczas stopniową kodyfikację międzynarodowego prawa karnego czyni odtworzenie ich treści przez jednostkowego adresata zadaniem w zasadzie niewykonalnym. W świetle przywołanego powyżej wyroku w sprawie Jorgic, prima facie można więc stwierdzić, że na początkowym etapie rozwoju międzynarodowego prawa karnego, standard ochronny określony przez zasadę legalizmu we współczesnym międzynarodowym prawie praw człowieka nie zostałby spełniony. Czy metoda formułowania zakazów karnych we współczesnym międzynarodowym prawie karnym na ich spełnienie pozwala, pozostaje odmienną kwestią.

W istocie można podnieść argument, że wątpliwe jest to, czy „Zwykły” adresat normy karnoprawnej rzeczywiście posiada zdolność odtworzenia zakazu zakodowanego w lex non scripta bez uwzględnienia kontekstu „dostępności moralnej” takiego zakazu. W przypadku zwyczaju międzynarodowego, wywiedzenie treści normy wiązałoby się z koniecznością identyfikacji spójnej praktyki państw oraz przekonania o wiążącej mocy takiego zakazu (opinio juris) ${ }^{11}$. W odniesieniu do ogólnych zasad prawa uznanych przez społeczność międzynarodową wymagałoby to natomiast przeprowadzania wieloaspektowej analizy rozwiązań normatywnych składających się na pewien model postępowania, który dopiero w przypadku stwierdzenia spójności wewnętrznych rozwiązań normatywnych mógłby zostać przeniesiony na poziom międzynarodowy. Trudno nie stwierdzić, nawiązując do wyrażonej już powyżej opinii J. Gardnera,

11 Por. N. ArAJÄRvi, The changing nature of customary international law: methods of interpreting the concept of custom in international criminal tribunals, London-New York 2014, s. 120-142. Zwłaszcza w prawie zwyczajowym często trudno w jednoznaczny sposób określić moment, od którego dana norma zaczęła obowiązywać. W kontekście zakazu jest to tym trudniejsze, że trzeba byłoby wykazać, dlaczego państwa nie dopuszczają się określonej zbrodni, co jest w praktyce niemożliwe, jeżeli kwestia ta nie jest explicite dyskutowana na forum międzynarodowym. Dla stosowalności normy karnoprawnej to niedookreślenie znaczeniowe i temporalne prawa zwyczajowego jest problematyczne o tyle, że moment wejścia w życie normy prawnej ma przecież fundamentalne znaczenie z perspektywy możliwości rozpoznania karalności określonego czynu oraz kompetencji do pociągania do odpowiedzialności karnej za jego popełnienie. O wiążącym charakterze takiej normy można by z większą dozą pewności mówić dopiero po pierwszym wyroku skazującym. 
że nie jest to zadanie wykonalne dla „zwykłego” adresata normy karnoprawnej; może ono zresztą stanowić także spore wyzwanie nawet dla doświadczonego prawnika ${ }^{12}$.

Wydanie ostatecznej oceny, gdy idzie o spełnienie poszczególnych kryteriów międzynarodowej zasady legalizmu, nie jest jednak, co jasne, możliwe in abstracto, gdyż zależy od specyfiki konkretnej sytuacji faktycznej oraz normy jej odpowiadającej ${ }^{13}$. Przykłady orzecznicze zostaną z tego względu omówione poniżej. Nie ulega jednak wątpliwości, że niedookreślenie katalogu źródeł kryminalizacji oraz odejście od wymogu lex scripta pozostawia w praktyce spore pole interpretacyjne sądowi badającemu potencjalne naruszenie zasady legalizmu a casu ad casum, obniżając w ten sposób rzeczywisty standard gwarancyjny samej zasady ${ }^{14}$.

Z kolei możliwość spełnienia dwóch podstawowych dyrektyw lex certa, tj. przewidywalności (foreseeability) oraz dostępności (accessibility) informacji kryminalizacyjnej przez wspomniane źródła prawa międzynarodowego wymaga uwzględnienia charakteru analizowanego naruszenia ${ }^{15}$, jak i szerszego kontekstu delimitowanego przez stadium rozwoju międzynarodowego prawa karnego ${ }^{16}$. Jasne jest, że czy to z racji

12 Przykładowo, w sprawie Jorgic odnoszącej się do transponowanej na poziom krajowy (RFN) zbrodni ludobójstwa, ETPC zauważył, że „w istotnym dla okoliczności sporu momencie, zakres art. 2 Konwencji o ludobójstwie, na którym bazuje art. 220a Kodeksu karnego, był przedmiotem sporów wśród badaczy, gdy idzie o definicję «zamiaru zniszczenia grupy»": Jorgic p. Republice Federalnej Niemiec, pkt 111.

13 „Kwestia ta musi być oceniana dla każdej sprawy osobno, biorąc pod uwagę specyficzne okoliczności każdej sprawy” - wyrok Wielkiej Izby ETPC z 18 lipca 2013 r. w sprawie Maktouf oraz Damjanović p. Bośni i Hercegowinie, skargi nr 2312/09 oraz 34179/08, pkt 65.

14 W podobnym tonie: F.O. RaImondo, General principles of law in the decisions of international criminal courts and tribunals, Amsterdam 2007, s. 144-145.

15 Maktouf oraz Damjanović p. Bośni i Hercegowinie, pkt 65.

16 Kononov p. Łotwie, pkt 238-239, 244. 
niepisanego charakteru (zwyczaj ${ }^{17}$, ogólne zasady ${ }^{18}$ ), czy też niejasnych sformułowań, jak i potencjalnych barier językowych (umowa międzynarodowa), źródła prawa międzynarodowego mogą realizować powyższe dyrektywy wyłącznie do pewnego stopnia. Ponownie zatem standard ten $\mathrm{z}$ normatywnej perspektywy nie będzie odpowiadał temu, który stosuje się do oceny legislacji krajowej.

Konstatację tę łagodzi jednak, do pewnego przynajmniej stopnia, wspomniana wcześniej perspektywa kontekstu i charakteru naruszenia (dostępność moralna). Skoro w oparciu o umowy międzynarodowe, zwyczaj międzynarodowy oraz ogólne zasady prawa uznane przez społeczność międzynarodową kryminalizuje się z reguły najcięższe naruszenia praw człowieka, które podlegają powszechnej kryminalizacji także na poziomie krajowym, to i wspomniane dyrektywy lex certa mogą być uznane za spełnione, nawet jeśli analogicznego wniosku nie można by poczynić w odniesieniu do wymogów określających zasadę legalizmu w kontynentalnej kulturze prawnej ${ }^{19}$. Takie rozumowanie ETPC wywieść można chociażby ze sprawy Jorgic, w której Trybunał analizował, czy sprawca zbrodni popełnionych w trakcie konfliktu jugosłowiańskiego mógł rozpoznać, że podejmując określone działania, ryzykuje popełnienie zbrodni ludobójstwa. Mimo rozbieżnych interpretacji poszczególnych elementów konstytutywnych tej zbrodni, wpływających - co oczywiste - na standard przewidywalności, zdaniem ETPC Jorgic był w stanie rozpoznać karalny charakter swoich czynów w chwili ich

17 Norma zwyczajowa może bowiem posiadać analogiczną treść co norma traktatowa. W takim przypadku norma zwyczajowa będzie zatem posiadała charakter lex scripta. Oprócz tego, norma zwyczajowa może zostać zidentyfikowana i sprecyzowana w orzecznictwie sądowym, co także nada jej charakter normy „spisanej”. Por. Prokurator p. M. Milutinović et al. (MTKJ), Decision on Drajgoljub Ojdanić's Motion Challenging Jurisdiction - Joint Criminal Enterprise, 21 maja 2003 r., IT-99-37-AR 72, pkt 41.

18 Ogólne zasady posiadają pośrednio pisany charakter, gdyż są wywodzone z prawa krajowego.

19 W tym też przejawia się dystynkcja pomiędzy zawężającym ujęciem legalizmu (strict legality) a mniej rygorystycznym podejściem materialnym (substantive justice) opartym na rozumowaniu celowościowym, które charakteryzuje międzynarodową zasadę legalizmu. Por. A. CAssese et al., Cassese's International Criminal Law, Oxford 2013, s. 23-26. 
podjęcia. Dochodząc do tego wniosku, Trybunał „miał także na względzie fakt, że wnioskodawca został skazany za czyny o znacznym ciężarze oraz czasie trwania" ${ }^{20}$. W tym też wyraża się, choćby niewysłowiona explicite, „dostępność moralna” komunikatu kryminalizacyjnego na poziomie międzynarodowym.

W orzecznictwie ETPC regularnie podkreśla się, że przestępstwo powinno być w sposób czytelny zdefiniowane przez prawo, przez co rozumie się zarówno jego warstwę słowną, jak i następczą interpretację sądową danego typu czynu zabronionego ${ }^{21}$. W zakresie, w jakim międzynarodowa zasada legalizmu odnosi się do przestępstw międzynarodowych, ETPC co do zasady nie wywodzi z niej jednak wymogu dokładnego określenia poszczególnych elementów tworzących określony typ $\mathrm{p}^{22}$. W sprawach dotyczących przestępstw międzynarodowych, które podlegają wykładni zarówno na poziomie międzynarodowym, jak i krajowym, gwarancja ta ogranicza się do ogólnej zdolności identyfikacji czynów karalnych, a nie całości materiału normatywnego determinującego bezprawność danego zachowania. Trybunał odwołuje się $\mathrm{w}$ tym względzie do tzw. trzonu przestępstwa (essence of the offence) ${ }^{23}$. Spełnienie wymogu lex stricta, tj. wykładnia w zgodzie z przyjętym rozumieniem trzonu przestępstwa międzynarodowego przez sąd krajowy, stanowi pozytywną przesłankę na rzecz uznania, że skarżący posiadał zdolność przewidzenia karalności podejmowanego przez siebie zachowania (lex certa) ${ }^{24}$.

W praktyce problematyczna jest jednak dopuszczalność wyboru określonej ścieżki interpretacyjnej przez sąd krajowy, która może być

20 Jorgic p. Republice Federalnej Niemiec, pkt 113.

${ }_{21}$ M.in. Vasiliauskas p. Litwie, pkt 153; jeżeli taka interpretacja istnieje, pojawia się dodatkowy wymiar kontroli odnoszącej się do jej spójności. W przypadku jej braku, problem taki nie zachodzi.

22 M. Timmerman, Legality in Europe. On the principle 'nullum crimen, nulla poena sine lege' in EU law and under the ECHR, Cambridge-Antwerp-Portland 2018, s. 101.

23 Jorgic p. Republice Federalnej Niemiec, pkt 103-108.

24 Ibidem, pkt 109 (jest to jednak przesłanka, którą można obalić, o ile skarżący wykaże, że podejmując określone działanie, opierał się na konkretnej wykładni trzonu przestępstwa). 
odmienna od tej przyjmowanej przez inne organy sądowe. Przykładowo, we wspomnianej już sprawie Jorgic sąd niemiecki przyjął szerszą wykładnię elementu zbrodni ludobójstwa aniżeli trybunały międzynarodowe. To jednak, zdaniem ETPC, nie stanowiło naruszenia zasady legalizmu, ponieważ wciąż mieściło się w szeroko rozumianym trzonie tego typu przestępstwa $^{25}$.

W świetle powyższych uwag trudno jednak nie stwierdzić, że przewidywalność kryminalizacji międzynarodowej będzie mieć z zasady charakter kontekstowy. Kontekstowość ma przy tym szerszy zakres aniżeli w przypadku przestępstw zwykłych, właśnie z tego powodu, że wymaga ona uwzględnienia różnych wymiarów normatywnych oraz rozproszonych centrów interpretacji (międzynarodowej, krajowej). Jednostka musi zatem znać nie tylko treść zakazu w określonym systemie, ale i jego następczą wykładnię, która może czasem podążać w rozbieżnych kierunkach.

Wymóg lex certa jest w orzecznictwie kwalifikowany przez tzw. obiektywny i subiektywny wymiar decyzji kryminalizacyjnej.

Ten pierwszy - obiektywny aspekt przewidywalności - zogniskowany jest wokół charakteru naruszonego dobra ${ }^{26}$. W przypadku czynów kwalifikowanych jako zbrodnie międzynarodowe trudno jest argumentować i zaakceptować twierdzenie, że nie wiedziało się o nielegalności podejmowanych działań ${ }^{27}$. Wszak działania te naruszają podstawowe wartości i, jako takie, nie mogą być uznane za zgodne z prawem nawet

25 Ibidem, pkt 114.

26 Ten merytoryczny aspekt przewidywalności wywieść można m.in. z następujących orzeczeń (zgwałcenie, przemoc domowa): wyrok ETPC z 10 października 2006 r. w sprawie Pessino p. Francji, skarga nr 40403/02, pkt 36; wyrok Wielkiej Izby ETPC z 27 stycznia 2015 r. w sprawie Rohlena p. Republice Czeskiej, skarga nr 59552/08, pkt 71. W kontekście zbrodni międzynarodowych - „Zakres koncepcji przewidywalności zależy w dużej mierze od zawartości analizowanego instrumentu, dziedziny, którą ma on regulować, oraz liczby i statusu osób, do których jest zaadresowany: Vasiliauskas p. Litwie, pkt 157; Kononov p. Łotwie, pkt 235; wyrok Wielkiej Izby ETPC z 19 września 2008 r. w sprawie Korbely p. Wegrom, skarga nr 9174/02, pkt 95.

27 Prokurator p. M. Milutinović et al., pkt 39-42; Jorgic p. Republice Federalnej Niemiec, pkt 113 (długotrwały charakter oraz ciężar czynów skarżącego (tut. ludobójstwo) jako przesłanka braku naruszenia konwencji). 
przez osobę nieświadomą tego, że jej czyn może być oznaczony (labelling) jako zbrodnia międzynarodowa w postępowaniu sądowym ${ }^{28}$. W ujęciu tym wyraźnie wybrzmiewa forma normatywnego ugruntowania relacji pomiędzy dostępnością tekstową a dostępnością moralną decyzji kryminalizacyjnej.

Natomiast aspekt subiektywny dotyczy możliwości przewidzenia bezprawności i karalności określonego czynu przez konkretną jednostkę w związku z jej pozycją zawodową oraz sytuacją, w której się znalazła $^{29}$, jak i możliwością zasięgnięcia stosownej porady prawnej ${ }^{30}$. W sprawie Kononov podkreślono chociażby, że od dowodzącego oficera można oczekiwać zachowania szczególnej ostrożności przy podejmowaniu decyzji opatrzonych tak dużym ryzykiem jak operacja zbrojna

28 W kontekście zbrodni przeciwko ludzkości i możliwości wywiedzenia ich nielegalnego charakteru (foreseeability) z będącej swoistą klauzulą moralności, tzw. klauzuli Martensa - C. Tomuschat, The Nuremberg Legacy, «Journal of International Criminal Justice» 4/2006, s. 835. Trybunały międzynarodowe uznają, że wymóg przewidywalności zostaje spełniony także w sytuacji, gdy sprawca mógł - co prawda - przewidzieć karalny charakter swojego zachowania (actus reus), lecz niekoniecznie elementów kontekstowych odróżniających zbrodnie międzynarodowe od przestępstw zwykłych kryminalizowanych wyłącznie na poziomie krajowym (np. morderstwo jako zbrodnia przeciwko ludzkości). Por. wyrok MTKJ z 16 listopada 1998 r. w sprawie Prokurator p. Zejnil Delacić, Zdravko Mucić, Hazim Delić oraz Esad Landžo, IT-96-21-T, pkt 312.

29 Element subiektywny związany jest $\mathrm{z}$ adresatem danej normy. Por. wyrok ETPC z 6 kwietnia 2010 r. w sprawie Flinkkilä $i$ inni p. Finlandii, skarga nr 25576/04, pkt 66-67(będący dziennikarzami wnioskodawcy nie mogą powoływać się na nieznajomość zakazów dotyczących ochrony życia prywatnego związanych z wykonywanym przez nich zawodem). Osoby prowadzące działalność zawodową muszą zachowywać wyższy poziom ostrożności przy jej wykonywaniu - m.in. Pessino p. Francji, skarga nr 40403/02, 10 października 2006 r., pkt 33.

$30 \mathrm{~W}$ odniesieniu do przestępstw międzynarodowych wymóg ten pojawia się przede wszystkim przy „mechanicznym” relacjonowaniu obowiązującego standardu orzeczniczego w ramach art. 7 EKPC. Por. Kononov p. Łotwie, pkt 185; Vasiliauskas p. Litwie, pkt 154-157. W praktyce jednak zdaje się odgrywać niewielką rolę jako podstawa odrzucenia zarzutu naruszenia konwencji w tego typu sprawach. 
w jednej z łotewskich wsi, która skutkowała popełnieniem przez Kononova zbrodni wojennych ${ }^{31}$. Nie jest to zresztą odosobniony przypadek ${ }^{32}$.

Tak czy inaczej, można podać w wątpliwość, czy biorąc pod uwage niedookreślony charakter wielu przestępstw międzynarodowych, zwłaszcza na początkowym etapie rozwoju międzynarodowego prawa karnego, możliwość uzyskania porady prawnej rzeczywiście pozwalałaby na dokładne określenie lex lata i w tym sensie stanowiłaby istotną zmianę jakościową ${ }^{33}$. Podobne nieścisłości interpretacyjne są zresztą częścią dyskursu w obrębie prawa karnego międzynarodowego także w czasach nam bliższych. We wspomnianej już sprawie Jorgic Trybunał skonkludował, że „skarżący, gdyby zaszła taka potrzeba z pomocą prawnika, mógł rozsądnie przewidzieć, iż dopuszczając się w 1992 r. czynów [wypełniających w przybliżeniu opis zbrodni ludobójstwa, jak i innych zbrodni - P.G.] podejmuje ryzyko oskarżenia i skazania" za tę zbrodnię ${ }^{34}$.

Przyjęty przez ETPC standard przewidywalności nie powinien być więc zestawiony z pewnością tego, że czyn a jest czynem zabronionym, lecz raczej z możnością rozpoznania („ryzykiem”) jego karalności, nawet jeśli źródło takiej konstatacji nie jest łatwe do zlokalizowana pośród odmiennych stanowisk doktrynalnych i orzecznictwa sądowego. W orzecznictwie podkreśla się w tej mierze, że przewidywalność musi być analizowana $\mathrm{w}$ sprzężeniu $\mathrm{z}$ konkretnym zarzutem stawianym sprawcy. Jeżeli sprawca zostanie skazany za zbrodnię wojenną, to test przewidywalności w ramach art. 7 EKPC odnosić się powinien do tej, a nie innej zbrodni międzynarodowej ${ }^{35}$. Trybunał analizuje zatem to, czy wnioskodawca mógł przewidzieć, że dane zachowanie stanowi okre-

31 Kononov p. Eotwie, pkt 238.

32 W sprawie Streletz, Kessler oraz Krenz p. Republice Federalnej Niemiec ETPC poczynił analogiczną uwagę w odniesieniu do „stanowisk wysokiego stopnia w aparacie państwowym" (ibidem, pkt 78).

33 Zwłaszcza w przypadku niektórych zbrodni popełnianych w latach 40. w trakcie trwającego konfliktu zbrojnego. Podobnie w kontekście wydarzeń w NRD w 1972 r. por. częściowo odrębne zdanie sędziego Cabrala Baretto, sprawa K.-H.W. p. Republice Federalnej Niemiec, pkt 3; problemy ze sprecyzowaniem mają wszak także sędziowie por. F.O. RaImONDO, op. cit., s. 145.

34 Jorgic p. Republice Federalnej Niemiec, pkt 110, 113.

35 Por. Kononov p. Łotwie, pkt 187, 239. 
ślony typ zbrodni i że może być on oskarżony o jej popełnienie, nie zaś to, czy sprawca mógł w ogóle przewidzieć, iż jego czyn jest bezprawny, a nawet karalny ${ }^{36}$. Nie oznacza to oczywiście, że drugi ze wskazanych elementów nie jest konieczny do wykazania przy analizie wymogu przewidywalności. Próg standardu przewidywalności zdaje się jednak w praktyce wyższy właśnie $z$ racji przyjęcia wspomnianego sprzężonego modelu analizy (zarzut - skazanie - przewidywalność).

W sytuacji rozbieżności wykładniczych, wybór określonej ścieżki interpretacyjnej danego typu zbrodni międzynarodowej przez sąd krajowy nie będzie stanowił naruszenia art. 7 EKPC. Oznacza to, że we wspomniane „ryzyko karalności” wpisany jest także wymóg świadomości jednostki co do istnienia różnych linii interpretacyjnych określonych typów przestępstw międzynarodowych. Wybór jednej z nich przez wnioskodawcę, w sytuacji, gdyby była ona odmienna od tej obranej post factum przez sąd, nie będzie jednak traktowany jako jego „tarcza” przed skazaniem, a ponadto jako podstawa twierdzenia, że wyrok karny sądu krajowego naruszył art. 7 EKPC, o ile interpretacja przyjęta przez sąd była możliwa do wywiedzenia $\mathrm{z}$,trzonu zbrodni” i nie stanowiła oczywistego naruszenia granic dopuszczalnej wykładni ${ }^{37}$. Równie istotne znaczenie ma w tym kontekście dozwolona w świetle art. 7 EKPC stopniowa klaryfikacja znamion zbrodni ${ }^{38}$, której potencjalny sprawca musi być również świadomy. Kolejny przejaw „utopii legalizmu”.

Formalny aspekt lex certa, tj. dostępność informacji kryminalizacyjnej (accessibility), posiada niesprecyzowany charakter w orzecznictwie sądowym ${ }^{39}$. Europejski Trybunał Praw Człowieka regularnie odnosi się, co prawda, do spełnienia wymogu dostępności jako elementu dookreślającego lex lata, jednak trudno nie odnieść wrażenia, że z merytorycznej perspektywy analiza tego wymogu ma w rzeczywistości charakter poboczny. W przypadku tzw. przestępstw zwykłych, zakodowanie określonego zakazu karnego w przepisie ustawy lub innego aktu praw-

36 Ibidem, pkt 239.

37 Taki wniosek można wywieść z: Jorgic p. Republice Federalnej Niemiec, pkt 114. Daje to, co oczywiste, pewną swobodę interpretacyjną sądom krajowym.

38 Por. Vasiliauskas p. Litwie, pkt 155.

39 Kononov p. Łotwie, pkt 237; Vasiliauskas p. Litwie, pkt 167-168. 
nego, jak i publiczna dostępność orzecznictwa następczo taki przepis dookreślającego uznawana jest za dowód spełnienia tego wymogu $\mathrm{u}^{40}$. Standard ten nie jest jednak możliwy do bezpośredniego przełożenia na „prawo międzynarodowe” (art. 7 ust. 1 EKPC), zaś autonomiczne kryteria towarzyszące ocenie dostępności komunikatu kryminalizacyjnego w odniesieniu do zbrodni międzynarodowych nie zostały dotąd sprecyzowane. Z praktyki orzeczniczej ETPC wywieść można mało restrykcyjny test kontroli ${ }^{41}$. Przykładowo, w sprawie dotyczącej zarzutu popełnienia zbrodni przeciwko ludzkości, ETPC stwierdził, że wymóg dostępności zostanie spełniony, jeżeli możliwa była identyfikacja jakiegokolwiek dokumentu potwierdzającego kryminalizację danego czynu ${ }^{42}$.

Nie ulega przy tym wątpliwości, że w przypadku międzynarodowego prawa karnego wymóg „dostępności” musi z istoty rzeczy przybrać odmienną postać niż w prawie wewnętrznym, jako że prawo międzynarodowe nie operuje przecież jednym, powszechnym dziennikiem umów międzynarodowych i innych źródeł tego prawa na podobieństwo publikatorów krajowych (np. Dziennik Ustaw). Ponadto w odniesieniu do źródeł niepisanych, na przykład międzynarodowego zwyczaju, trudno byłoby wyobrazić sobie spełnienie takiego „mechanicznego aspektu” zasady legalizmu, tj. publikacji treści zwyczaju w określonym prawem i publicznie dostępnym dokumencie ${ }^{43}$. Wymóg „dostępności” nie ma zatem precyzyjnego charakteru. Charakteryzuje się on także niewielkimi walorami gwarancyjnymi w sferze kryminalizacji międzynarodowej.

Dostępność komunikatu kryminalizacyjnego jest w rezultacie często analizowana w sprzężeniu z wymogiem przewidywalności ${ }^{44}$. To wymóg przewidywalności staje się jednak wówczas podstawowym punktem

40 Por. wyrok ETPC z 27 września 1995 r. w sprawie G. p. Francji, skarga nr 15312/89, pkt 25-26.

${ }^{41}$ Jest to wymóg, który nie jest trudno spełnić - tak M. Timmerman, op. cit., s. 99.

42 Dopuszczenie mniej standardowej formy poinformowania o obowiązującym prawie (broszura) - Korbely p. Wegrom, pkt 74-75.

43 Wniosek taki wywieść można m.in. z: Prokurator p. E. Hadzihasanovic et al. (MTKJ), Decision on Interlocutory Appeal Challenging Jurisdiction in Relation to Command Responsibility, 16 lipca 2003 r., IT-01-47-AR72, pkt 34.

44 Wówczas jednak perspektywa dostępności staje się niejako „tłem” dla analizy przewidywalności. Łączną analizę obu perspektyw lex certa ETPC dopuścił m.in. 
odniesienia przy ocenie spełnienia wymogu pewności prawa (lex certa). Naruszenie zasady legalizmu z reguły wiązać się będzie więc z niespełnieniem albo kryteriów formalnych (tj. testu obowiązywania prawa i odpowiedniego oparcia wyroku karnego), albo wymogów materialnych, w tym przede wszystkim wymogu przewidywalności, a nie dostępności komunikatu kryminalizacyjnego.

\subsection{Nulla poena sine lege?}

Za szczególnie kontrowersyjne w odniesieniu do wszystkich źródeł prawa międzynarodowego uznać należy stosowalność wymogu uprzedniego normatywnego określenia sankcji karnej grożącej za popełnienie danego czynu (nulla poena sine lege). W kontekście wymogu przewidywalności i dostępności (lex certa), podstawowa kwestia tyczy się oczywiście tego, czy jednostka w chwili podjęcia określonego zachowania posiadała nie tylko możność rozpoznania jego bezprawności i karalności, lecz także wymiaru oraz rodzaju grożącej za nie sankcji ${ }^{4}$. W orzecznictwie ETPC odnotować można niejako mechanicznie czynione odniesienia do skumulowanej zasady nullum crimen, nulla poena sine lege; mechanicznie - gdyż pomimo przytaczania samej formuły, w sprawach dotyczących zbrodni międzynarodowych Trybunał nie podejmował dotąd szczegółowej analizy poszczególnych jej aspektów oraz tego, czy rzeczywiście została ona w konkretnej sprawie spełniona ${ }^{46}$.

Merytoryczne wątpliwości budzi przede wszystkim to, czy, a jeżeli tak, to do jakiego stopnia, wskazana powyżej gwarancja nulla poena jest (mogłaby być) zachowana przy kryminalizacji międzynarodowej ${ }^{47}$.

w sprawie Kononov p. Łotwie, pkt 235-237 (brak publikacji nie był zdaniem Trybunału decydujący właśnie ze względu na przewidywalność karalnego charakteru czynów).

45 Por. wyrok ETPC z 24 stycznia 2017 r. w sprawie Koprivinkarp. Słowenii, skarga nr 67503/13, pkt 47; wyrok ETPC z 21 października 2013 r. w sprawie Del Río Prada p. Hiszpanii, skarga nr 42750/09, pkt 79.

46 M.in. wyrok ETPC z 25 maja 1993 r. w sprawie Kokkinakis p. Grecji, skarga nr 14307/88, pkt 52; wyrok ETPC z 8 lipca 1999 r. w sprawie Başkaya i Okçuoğlu p. Turcji, skargi nr 23536/94 oraz 24408/94, pkt 36-42; wyrok ETPC z 22 lipca 2003 r. w sprawie Gabarri Moreno p. Hiszpanii, skarga nr 68066/01, pkt 23.

47 Twierdząco: G. Werle, F. Jessberger, Principles of International Criminal Law, Oxford 2014, s. 40. 
Problem ten znajduje odzwierciedlenie we wszystkich umowach z zakresu międzynarodowego prawa karnego, które - z wyjątkiem traktatów konstytuujących trybunały międzynarodowe (m.in. art. 77 Statutu Międzynarodowego Trybunału Karnego ${ }^{48}$ ) - nie zawierają stosownych katalogów sankcji karnych grożących za popełnienie zbrodni w nich określonych. Z natury rzeczy podobny brak zaobserwować można w odniesieniu do prawa zwyczajowego i zasad prawa uznanych przez społeczność międzynarodową. Trudno więc mówić o dostępności takiej informacji, skoro źródła prawa międzynarodowego co do zasady nie precyzują charakteru i wymiaru sankcji grożącej za naruszenie jego norm.

Standard nulla poena sine lege został, co prawda, wspomniany w toczących się już po zakończeniu II wojny światowej procesach zbrodniarzy wojennych przed międzynarodowymi, jak i krajowymi sądami karnymi, lecz jego dokładny wymiar przybrał wówczas postać dosyć wyszukanej, acz mało przekonującej argumentacji. Chociażby w sprawie Rautera $^{49}$, sąd holenderski, podążając za „argumentacją norymberską", stwierdził, że przewidywalność kary nie ma charakteru absolutnego i musi podlegać ważeniu ${ }^{50}$. W wyroku tym wskazano ponadto, iż „[w] prawie kontynentalnym [...] jest to [tj. przewidywalność sankcji - P.G.] kwestia o zasadniczym znaczeniu, jako że sankcje karne są wyrażone przez prawo ustawowe w czytelny sposób oraz z wyznaczeniem konkretnej sankcji [...] za każdy czyn zabroniony [...]"51. W odniesieniu jednak do zbrodni wojennych oraz zbrodni przeciwko ludzkości wprowadzenie jednoznacznych przepisów określających typ i surowość sankcji karnej nie było - zdaniem sądu - niezbędnym wymogiem ${ }^{52}$. Kluczowy był zaś fakt, aby ze względu na swą powagę, „zbrodnia zasługiwała na karę wedle standardów sprawiedliwości karnej narodów cywilizowanych" ${ }^{33}$.

48 Rzymski Statut Międzynarodowego Trybunału Karnego sporządzony w Rzymie 17 lipca 1998 r. (Dz. U. z 2003 r. Nr 78, poz. 708).

49 Trial of H.A. Rauter, Netherlands Special Court, wyrok z 12 stycznia 1949 r., s. 119.

$50 \quad$ Ibidem, s. 119.

51 Ibidem, s. 120.

52 Ibidem, s. 120.

53 Ibidem, s. 120-121. 
Brak określonej sankcji w aktach prawnych będących normatywną podstawą wydawanych wówczas wyroków nie powinno być jednak odczytywane jako argument na rzecz uznania niekaralnego charakteru wyszczególnionych w nich czynów. Przeciwnie - oznaczoność kary nie przesądza o tym, czy określone zachowanie jest traktowane jako zbrodnia w międzynarodowym prawie karnym ${ }^{54}$.

To zawoalowane rozumowanie sądu holenderskiego w duchu norymberskim zostało przejęte po latach także przez trybunały ad hoc ${ }^{55}$. Mimo że sama zasada nulla poena widniała w rozumowaniach tych trybunałów, przez wiele lat - aż do utworzenia Międzynarodowego Trybunału Karnego - jej standard gwarancyjny w międzynarodowych procesach karnych był w zasadzie nieistniejący. Sama zaś określoność kary była uznawana za szczegół; fakt, że czyn był moralnie naganny, stanowił wystarczającą podstawę do stwierdzenia, iż sprawca był w stanie przewidzieć jego bezprawność; to z kolei stanowiło wystarczającą podstawę do przewidzenia jego karalności, a ponadto uzasadniało surowość grożącej, nawet jeśli zakresowo niedookreślonej w jakimkolwiek zakresie, sankcji karnej. Skoro bowiem czyny, o których mowa, cechowały się wysokim kwantum karygodności, to i kara grożąca za ich popełnienie musiała być odpowiednio surowa. Sprawca powinien był więc przewidzieć także ten aspekt odpowiedzialności, podejmując określone, prawnie relewantne działanie.

Obecnie problem ten nie przybiera podobnej postaci w związku z tym, że art. 77 SMTK przewiduje katalog sankcji karnych grożących za popełnienie zbrodni objętych prospektywną jurysdykcją MTK. Trudno jednak stwierdzić, jakoby sankcje w przepisie tym zawarte miały oznaczony (nawet względnie) charakter, skoro jedyną gwarancję możliwą do wywiedzenia $\mathrm{z}$ jego treści jest zakaz stosowania kary śmierci oraz ograniczenia w zakresie orzekania kary dożywotniego pozbawienia wolności. Ten niedookreślony format wymiaru możliwej do orzeczenia

$54 \quad$ Ibidem, s. 121.

55 Np. orzeczenie MTKJ o wymiarze kary z 29 listopada 1996 r. w sprawie Prokurator p. D. Erdemovic, IT-96-22-T, pkt 38. 
kary wyposaża trybunały międzynarodowe w prawie nieograniczoną władzę dyskrecjonalną na etapie miarkowania konkretnej sankcji ${ }^{56}$.

Mimo relatywnie bogatego orzecznictwa, trybunały międzynarodowe nie wypracowały dotąd orzeczniczych standardów i dyrektyw, które umożliwiłyby uniformizację wymiaru orzekanych sankcji karnych, czego najbardziej widocznym skutkiem są odnotowywane w literaturze rozbieżności pomiędzy dolegliwościami nakładanymi przez poszczególne trybunały międzynarodowe ${ }^{57}$. Standard oznaczoności kar w międzynarodowym prawie karnym daleki jest więc od tego przyjmowanego w kontynentalnej kulturze prawnej ${ }^{58}$. Mniej problematycznie rysuje się natomiast $\mathrm{z}$ perspektywy zasady nulla poena sine lege ustawodawstwo krajowe odnoszące się do przestępstw klasyfikowanych jako zbrodnie międzynarodowe, gdzie rodzaje i zakresy sankcji karnych pozostają określone przy zachowaniu wzorców mających zastosowanie także do przestępstw zwykłych ${ }^{59}$.

Świadectwem systemowych braków międzynarodowego prawa karnego w kontekście zasady nulla poena sine lege jest ponadto mechanizm wywodzenia sankcji przyjęty przez ETPC w sprawie Kononova: „tam, gdzie prawo międzynarodowego nie określa sankcji za zbrodnie wojenne z wystarczającą klarownością, sąd krajowy może, w przypadku ustalenia

56 Zdaniem L. Gardockiego, „[...] naruszeniem zasady nulla poena sine lege byłoby pozostawienie sędziemu całkowitej swobody w wyborze rodzaju i wysokości kary (sankcja nieoznaczona)" (L. Gardocki, Prawo karne, Warszawa 2019, s. 20). Choć wskazany powyżej przykład art. 77 SMTK nie podpada pod kategorię sankcji nieoznaczonej (oznaczoność górnej granicy), to w praktyce jednak tak dalece nieprecyzyjne określenie katalogu sankcji prowadzi do analogicznych skutków, jak gdyby były to sankcje nieoznaczone.

57 Por. N. Amoury Combs, Seeking Inconsistency: Advancing Pluralism in International Criminal Sentencing, «The Yale Journal of International Law» 41/2016, s. 1-49.

58 Por. B. KRzAN, Obowiązywanie zasady nulla poena sine lege z perspektywy międzynarodowych trybunałów karnych, [w:] Prawo międzynarodowe. Idee a rzeczywistość, red. E. CAŁA-WACINKIEWICZ, [Legalis] („nie można automatycznie przenosić zasady legalizmu kar znanej z prawa krajowego w wersji maksymalistycznej na poziom międzynarodowego sądownictwa karnego").

59 Por. rozdział XVI ustawy z 6 czerwca 1997 r. - Kodeks karny (tekst jedn. Dz. U. z 2019 r., poz. 1950 ze zm.). 
winy sprawcy, ustalić sankcję karną na podstawie prawa krajowego"60. Trybunał dopuszcza zatem stosowanie rozumowania opartego na swoistej sankcyjnej analogii. Nieprzyjęcie takiego rozwiązania oznaczałoby, co jasne, że sądy krajowe nie byłyby w stanie orzekać kary wobec sprawców zbrodni na podstawie wtórnie wprowadzonej kryminalizacji krajowej zachowania dotychczas karalnego wyłącznie na podstawie prawa międzynarodowego. Jest to zatem zabieg ściśle pragmatyczny, czy też - z odmiennej, krytycznej perspektywy - kolejny przejaw interpretacji prowadzącej do rozluźnienia wymogów gwarancyjnych utożsamianych z zasadą legalizmu karnego.

W tym kontekście można oczywiście zastanowić się, czy zasada nulla poena sine lege ma w ogóle jakikolwiek sens z perspektywy gwarancyjnej. Wbrew rozpowszechnionym w literaturze i orzecznictwie poglądom można argumentować, że istotność wymogu określoności sankcji (rodzaju, zakresu) sprowadzać się powinna przede wszystkim do zakazu pogorszenia sytuacji prawnej sprawcy post factum, tj. orzeczenia kary na jego niekorzyść. Brak wyraźnego określenia rodzaju oraz zakresu sankcji pozostawiałoby sędziemu całkowitą swobodę wyboru dolegliwości karnej; niemożliwe byłoby więc udowodnienie rozbieżności pomiędzy pierwotnym i wtórnym zagrożeniem karą, ergo doszłoby do zanegowania zasady lex praevia, a niekiedy także zasady lex mitior ${ }^{61}$.

Można mieć jednak wątpliwości, czy rzeczywiście zasadę nulla poena sine lege w kontekście wymogów lex certa powinno sprowadzać się do założenia, zgodnie z którym istotą zasady legalizmu jest między innymi zagwarantowanie możliwości przewidzenia wymiaru i rodzaju sankcji przez potencjalnego sprawcę przestępstwa. Postulować można odmienne rozumienie tej zasady, zgodnie z którym jednostka powinna przede wszystkim posiadać możność rozpoznania bezprawności i karalności określonego zachowania, a nie grożącej za nie sankcji. W kryteria

60 Kononov p. Łotwie, pkt 212.

${ }_{61}$ Zasada lex mitior nie została wyrażona explicite w EKPC. Jest natomiast zakodowana m.in. w art. 15 ust. 1 MPPOiP, art. 49 ust. 1 KPP czy art. 24 ust. 1 Statutu MTK. W kontekście EKPC, por. jednak: wyrok Wielkiej Izby ETPC z 17 września 2009 r. w sprawie Scoppola v. Włochy (nr 2), skarga nr 10249/03 (lex mitior można wywieść także EKPC). 
określające istotę komunikatu kryminalizacyjnego nie powinno się w tym ujęciu wkomponowywać tej dyrektywy nulla poena sine lege, zgodnie z którą wymaga się, aby potencjalny sprawca mógł rozpoznać wymiar sankcji grożącej za popełnienie określonego czynu. Nie powinno więc chodzić o to, ażeby sprawca mógł dowiedzieć się, czy grozić mu będzie sankcja „x” czy „y”, oraz czy mógł on przewidzieć, że dopuszczając się czynu $\mu$, otrzyma karę „x+1” czy „x-1”.

Uzasadnienie takiej reinterpretacji zasady nulla poena sine lege zasadza się na pierwiastku funkcjonalnym. Obecne odczytanie zasady nulla poena sine lege może bowiem prowadzić do paradoksalnej sytuacji, o czym piszący te słowa miał okazję przekonać się także w praktyce, że sprawca będzie podejmował decyzję o tym, czy wspomniany czyn $\mu$ popełnić, czy też nie, w oparciu o rachunek zysków i strat dokonywany na podstawie ustawowego zagrożenia karą określonego typu czynu zabronionego. Obecna filozofia zasady nulla poena sine lege zdaje się zjawisko to poniekąd aprobować, choć czyni to zazwyczaj pod osłoną argumentacji odnoszącej się do prewencyjnej funkcji prawa karnego. W mojej ocenie prowadzi to jednak do wypaczenia zasady legalizmu, której komunikacyjność powinna umożliwić sprawcy niepodejmowanie działań podlegających kryminalizacji, nie zaś przewidzenie sankcji, która będzie mu groziła, jeżeli takie działania podejmie.

Nie ma przy tym wątpliwości, że sankcja grożąca za popełnienie czynu $\mu$ powinna odpowiadać, in abstracto, jego karygodności. Nie ma także wątpliwości, że określoność sankcji karnej powinna być postulowana i implementowana, gdyż jest niczym innym, jak praktyczną koniecznością - jedyną metodą umożliwiającą zapewnienie tego, by sądy nie będą posługiwały się sankcyjną analogią na niekorzyść sprawcy. Uzasadnienie zasady nulla poena sine lege powinno jednak, jak sądzę, przybrać tę właśnie, a nie przytoczoną wcześniej postać. Innymi słowy, to, czy sprawca mógł przewidzieć rodzaj i wymiar sankcji, powinno mieć $\mathrm{w}$ tym względzie znaczenie drugoplanowe. $\mathrm{W}$ każdym jednak przypadku sąd powinien orzekać karę wyłącznie w granicach przyznanego mu uprawnienia normatywnego, uwzględniając osobiste warunki sprawcy i okoliczności, w których doszło do popełnienia danego czynu zabronionego. 
Niezależnie jednak od tego, czy zaakceptuje się powyższe uwagi odnoszące się do filozofii zasady nulla poena sine lege, jasne jest, że gwarancja ta - przy jej ścisłym rozumieniu - nie znajduje obecnie rzeczywistego zastosowania na poziomie międzynarodowym w odniesieniu do tzw. przestępstw międzynarodowych ${ }^{62}$, chyba że - odnosząc się ponownie do sprawy Kononova - ustalona przez sąd krajowy sankcja karna za ich popełnienie byłaby niewspółmierna do ciężaru czynów, których dopuścił się sprawca ${ }^{63}$. Kryterium stosowanym w tym przypadku byłaby najprawdopodobniej „arbitralność” wywiedzionej, w drodze analogii z prawa krajowego i potencjalnie międzynarodowego orzecznictwa, kary ${ }^{64}$. Jest to jednak wyłącznie interpretacyjne domniemanie, ponieważ ETPC nie mierzył się dotychczas $z$ takim problemem. Jasne jest natomiast to, że nie dojdzie do naruszenia międzynarodowej zasady nulla poena sine lege, jeżeli katalog sankcji karnych grożących za popełnienie danej

62 A. Cassese, op. cit., s. 36; K.S. Gallant, The Principle of Legality in International and Comparative Criminal Law, Cambridge 2008, s. 223, 383-389 (rozróżnienie ścisłego i słabszego rozumienia zasady nulla poena); zdaniem K.S. Gallanta, prawo międzynarodowe spełnia zasadę nulla poena w drugiej, słabszej wersji. Jest to jednak pogląd nieprzekonujący, gdyż przyjęcie takiej interpretacji prowadzi do całkowitego „rozwodnienia” tej zasady, przez co traci ona jakiekolwiek znaczenie normatywne (gwarancyjne). Możliwość przewidzenia, że za czyn a grozi kara (prawdopodobnie surowa, maksymalnie nawet dożywotnie pozbawienie wolności), pozbawione jest jakiejkolwiek wartości informacyjnej. Przy braku wyraźnie określonej taryfy sankcji karnych, trudno także stwierdzić, czy sąd nie skazał danej osoby na karę surowszą (retroaktywność nulla poena; negacja lex mitior). Odmienny od K.S. Gallanta pogląd wyraził S. Zappalà, którego zdaniem oskarżony nie może wywieść jakichkolwiek praw z zasady nulla poena w międzynarodowym prawie karnym. Por. S. ZAPPALÀ, Human Rights in International Criminal Procedure, Oxford 2003, s. 196. Stanowisko to należy, w sensie interpretacyjnym, podzielić.

${ }^{63}$ Przykładowo, w kontekście kary śmierci, K. Ambos zauważa, że choć kara ta nie jest całkowicie zabroniona $\mathrm{z}$ perspektywy międzynarodowego prawa praw człowieka, to musi spełniać formalne kryterium dostępności oraz materialne kryterium dotyczące szczególnej powagi czynu zabronionego. Por. K. Aмвоs, 'Nulla Poena Sine Lege' in International Criminal Law, [w:] Sentencing and Sanctioning in Supranational Criminal Law, eds. R. Haveman, O. Olusanya, Antwerp-Oxford 2006, s. 24.

64 „Arbitralne oskarżenie, skazanie oraz ukaranie” - Streletz, Kessler oraz Krenz p. Republice Federalnej Niemiec, pkt 50. 
zbrodni międzynarodowej zostanie ustanowiony - czy to na poziomie międzynarodowym, czy to na poziomie krajowym - post factum.

W tym też sensie skonstatować można, że międzynarodowa zasada legalizmu nastawiona jest przede wszystkim na określoność typu czynu, w tym zwłaszcza jego sprzężoną z pierwiastkiem moralności przewidywalność, a nie na dostępność decyzji kryminalizacyjnej czy precyzyjne ujęcie grożącej za jego popełnienie sankcji.

\section{4. ŹróDŁA PRAWA MIĘDZYNARODOWEGO W KONTEKŚCIE ODPOWIEDZIALNOŚCI KARNEJ PRZED SĄDEM KRAJOWYM} A WYMOGI ZASADY LEGALIZMU

W kontekście przestępstw międzynarodowych szczególnie istotne w praktyce orzeczniczej ETPC są te sprawy, w których sąd krajowy wydaje wyrok za popełnienie przestępstwa podlegającego $\mathrm{w}$ danym momencie kryminalizacji wyłącznie na podstawie prawa międzynarodowego albo - na co wskazuje $\mathrm{M}$. Timmerman - w sytuacji, gdy czyn w chwili jego popełnienia podlegał kryminalizacji zarówno na podstawie prawa krajowego, jak i prawa międzynarodowego, przy czym to pierwsze nie spełniało wymogów zasady legalizmu ${ }^{65}$. Prawo międzynarodowe stanowi w tych przypadkach przysłowiową „ostatnią deskę ratunku” dla uzasadnienia wyroku karnego sądu krajowego.

Problem następczego pociągania do odpowiedzialności karnej na poziomie krajowym za czyn, który w chwili popełnienia miał zdaniem sądu krajowego stanowić zbrodnię międzynarodową kryminalizowaną

65 M. Timmerman, op. cit., s. 95. Warto przy tym zwrócić uwagę, że wraz z transpozycją norm prawa międzynarodowego do prawa krajowego może dojść do sytuacji, w której przyjęte rozumienie danego typu czynu zabronionego na poziomie krajowym będzie odmienne od tego, które jest przyjęte na poziomie międzynarodowym. Z perspektywy jednostki oraz standardu przewidywalności oznacza to, że jednostka musi być świadoma zakresu kryminalizacji w obu (lub większej liczbie) systemów prawnych. Por. Jorgic p. Republice Federalnej Niemiec, pkt 113; Vasiliauskas p. Litwie, pkt 170-178 (zbrodnia ludobójstwa obejmująca także grupy polityczne rozszerzająca tym samym kryminalizację międzynarodową). Maktouforaz Damjanović p. Bośni i Herzegowinie, pkt 65. 
wyłącznie na poziomie międzynarodowym, zostanie zaprezentowany poniżej w drodze zwięzłej analizy argumentacji ETPC w sprawach Korbely (zbrodnie przeciwko ludzkości), Konovov (zbrodnie wojenne) oraz Vasiliauskas (zbrodnia ludobójstwa).

W sprawie Korbely zarzut naruszenia art. 7 EKPC oparty został na formalnym kryterium, zgodnie z którym żaden czyn, którego wnioskodawca dopuścił się w 1956 r., nie stanowił wówczas zbrodni przeciwko ludzkości, za którą wnioskodawca mógłby być ścigany i skazany kilkadziesiąt lat później ${ }^{66}$. János Korbely podniósł także argument dostępności komunikatu kryminalizacyjnego, wskazując, że nie mógł znać treści konwencji genewskich, stanowiących - co kontrowersyjne ${ }^{67}$ - podstawę wyroku skazującego, w chwili podejmowania działań zmierzających do utrzymania porządku w trakcie trwającego wówczas powstania węgierskiego ${ }^{68}$. W celu stwierdzenia, czy doszło do naruszenia art. 7 EKPC, Trybunał podjął się analizy dwóch zagadnień: po pierwsze, czy zachowanie J. Korbelyego mogło zostać zakwalifikowane jako zbrodnia przeciwko ludzkości w 1956 r., biorąc pod uwagę ówczesne rozumienie tego typu zbrodni międzynarodowej; po drugie zaś, czy ofiara tych czynów (Tamás Kaszás) była osobą ${ }^{69}$, która nie brała czynnego udziału w działaniach

66 Korbely p. Wegrom, pkt 54.

67 Konwencje genewskie stanowią fragment prawa konfliktów zbrojnych i są podstawą wywodzenia bezprawności w odniesieniu do zbrodni wojennych, a nie zbrodni przeciwko ludzkości. Podobną wątpliwość wyraża J.A. Sweeney, The European Court of Human Rights in the Post-Cold War Era: Universality in Transition, Abingdon 2013, s. 61 .

68 Korbely p. Wegrom, pkt 60.

69 Ograniczenie to wynikało z błędów poczynionych przez sądy węgierskie, które ograniczyły swoje analizy do osoby T. Kaszása jako ofiary J. Korbelyego, co miało w świetle wspólnego art. 3 konwencji genewskich uzasadniać twierdzenie, że doszło do ataku na osobę chronioną i w rezultacie do popełnienia zbrodni przeciwko ludzkości. Tym błędem, wbrew argumentacji rządu węgierskiego, sąd krajowy niejako „związał ręce” ETPC, który nie mógł odnieść się do faktu, że w konsekwencji działań J. Korbelyego śmierć poniosły także inne osoby w trakcie odbijania posterunku policyjnego spod kontroli powstańców. Por. Korbely p. Wegrom, pkt 93. Jest wielce prawdopodobne, że gdyby sąd węgierski szerzej odniósł się do innych ofiar tego ataku, rezultat sprawy przed ETPC byłby odmienny. 
wojennych w znaczeniu wspólnego art. 3 konwencji genewskich (konflikt zbrojny nieposiadający charakteru międzynarodowego ${ }^{70}$.

Przeprowadzając analizę źródeł kryminalizacji zbrodni przeciwko ludzkości, Trybunał doszedł do wniosku, że wyrok sądu krajowego naruszył prawa skarżącego wynikające z art. 7 EKPC. Podstawą tej konkluzji nie było jednak niespełnienie wymogu przewidywalności komunikatu kryminalizacyjnego, gdyż tego zagadnienia Trybunał w ogóle nie badał, lecz fakt, że biorąc pod uwagę treść prawa międzynarodowego w 1956 r., zachowanie J. Korbelyego nie mogło zostać zakwalifikowane jako zbrodnia przeciwko ludzkości ${ }^{71}$.

Trudno nie zauważyć, że w omawianej sprawie naruszenie art. 7 EKPC wynikało - zdaniem większości ${ }^{72}$ - z błędnej interpretacji prawa międzynarodowego oraz błędnej subsumpcji, a nie z braku możliwości przewidzenia kryminalizacji zbrodni przeciwko ludzkości przez skarżącego. Ten dwustopniowy model analizy, tj. po pierwsze, poprawności interpretacji treści prawa międzynarodowego w kontekście konkretnego czynu sprawcy oraz, po drugie, przewidywalności tak oddalonego komunikatu kryminalizacyjnego, charakteryzuje zresztą wszystkie sprawy, w których wydany przez sąd krajowy wyrok skazujący oparty zostaje na normie karnoprawnej wywiedzionej w historycznie zorientowanej analizie z prawa międzynarodowego. Skoro zatem w 1956 r. nie można było, zdaniem Trybunału, skazać J. Korbelyego za popełnienie zbrodni przeciwko ludzkości w związku z czynem, którego się on wówczas dopuścił, to nie można zrobić tego także kilkadziesiąt lat później. W takiej sytuacji nieistotne pozostaje również to, czy skarżący mógł w ogóle przewidzieć karalność tych zbrodni w momencie, gdy podejmował określone działanie.

\footnotetext{
$70 \quad$ Ibidem, pkt 77.

71 Ibidem, pkt 95.

72 Krytycznie o przyjętej przez Trybunał metodzie analizy (zastosowania prawa do danego stanu faktycznego przez sąd krajowy) wypowiedzieli się niektórzy sędziowie w zdaniu odrębnym. Por. Korbely p. Węgrom, wspólne zdanie odrębne sędziów Lorenzena, Tulkensa, Zagrebelskiego, Fura-Sandstrom oraz Popović, pkt 2 („naszym zdaniem sądy krajowe znajdowały się w lepszej pozycji do oceny wszystkich dostępnych faktów i dowodów”).
} 
Spełnienie wymogów art. 7 ust. 1 EKPC w odniesieniu do prawa międzynarodowego jako podstawy odpowiedzialności karnej było także przedmiotem kontroli ETPC ${ }^{73}$ w sprawie Kononov. Trybunał podjął się rozstrzygnięcia, czy biorąc pod uwagę stan prawa międzynarodowego w 1944 r., istniały wówczas wystarczająco precyzyjne podstawy prawne do tego, ażeby czyny Vasilliego Kononova zakwalifikować jako zbrodnie wojenne ${ }^{74}$. Oprócz tego, Trybunał miał także za zadanie zbadanie, czy owe zbrodnie były wówczas zdefiniowane w taki sposób, że spełniały one w wystarczającej mierze kryteria dostępności oraz przewidywalności, tj. czy skarżący mógł wiedzieć, które czyny mogą skutkować jego odpowiedzialnością karną za zbrodnie wojenne w 1944 r. ${ }^{75} \mathrm{~W}$ wyroku Trybunał przyjął ponownie dwustopniowy test ${ }^{76}$, przy czym wyraźniej, aniżeli to miało miejsce w sprawie Korbely, podkreślona została konieczność zbadania przewidywalności kryminalizacji. W swoim rozumowaniu ETPC przytoczył zarówno regulacje wewnętrzne, jak i prawo genewskie oraz haskie, uznając je za relewantne wskaźniki bądź podstawy odpowiedzialności karnej za zbrodnie wojenne w 1944 r. ${ }^{77}$ Konstatacja Trybunału była następująca: mimo braku stosownych regulacji w prawie wewnętrznym ZSRR, prawo międzynarodowe kryminalizowało w 1944 r. jako zbrodnie wojenne zachowania, których dopuścił się V. Kononov ${ }^{78}$.

Odmiennym zagadnieniem było jednak to, czy skarżący mógł przewidzieć karalność swoich czynów jako zbrodni wojennych w chwili ich podjęcia. Analizując ten problem, Trybunał oparł swoje rozumowanie na dwóch przesłankach. Z jednej strony, z argumentacji ETPC bardzo silnie wybrzmiała kwestia moralnej dostępności zakazu w związku $\mathrm{z}$ „rażąco bezprawną naturą złego traktowania i zabójstwa dziewięciu

$73 \mathrm{~W}$ prawie łotewskim w przedmiotowej sprawie podstawa odpowiedzialności za te zbrodnie pojawiła się dopiero w 1993 r. Co istotne, zawierała ona odesłanie do prawa międzynarodowego („,as defined in the relevant legal conventions” - art. 68 ust. 3 kodeksu karnego z 1961 r.). Por. Kononov p. Łotwie, pkt 48, 196.

74 Ibidem, pkt 187.

75 Ibidem.

76 „Przyznanie Trybunałowi mniejszej kompetencji kontrolnej (power of review) pozbawiłoby art. 7 sensu" - ibidem, pkt 198.

77 Ibidem, pkt 213.

78 Ibidem, pkt 222, 227. 
mieszkańców wsi" (obiektywny aspekt przewidywalności) ${ }^{79}$. Z drugiej zaś strony, uwzględniono także pozycję Kononova jako dowódcy i wynikający z tego obowiązek zachowania „specjalnej troski przy ocenie ryzyka” związanego z podejmowaną operacją (subiektywny wymiar tej

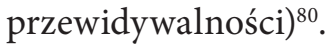

Sprawa Kononova świadczy także o tym, że dla oceny wymogu przewidywalności mało istotne znaczenie ma to, czy zawierający normę karnoprawną instrument (np. umowa, zwyczaj) został przyjęty (ratyfikowany) przez państwo pochodzenia wnioskodawcy w chwili popełnienia danego czynu ${ }^{81}$. Trudno nie zauważyć, że z perspektywy adresata normy karnoprawnej będącego obywatelem takiego państwa jest to standard relatywnie niski, dobitnie potwierdzający poczynioną już wcześniej uwagę o „tarciu” zachodzącym pomiędzy zasadą pewności prawa a multicentrycznością ośrodków kryminalizacji oraz interpretacji międzynarodowego prawa karnego. Jego zasadność jest jednak, zdaniem ETPC, wspierana charakterem chronionych dóbr prawnych przez normy kryminalizujące zachowania składające się na zbrodnie wojenne. Tym samym, w ocenie Trybunału nie doszło do naruszenia art. 7 ust. 1 EKPC w przedmiotowej sprawie, gdyż Kononov mógł przewidzieć w 1944 r., że „zarzucane czyny mogą być zakwalifikowane jako zbrodnie wojenne”82.

Zbrodni ludobójstwa dotyczyła natomiast sprawa Vasiliauskas. W tym przypadku ETPC miał za zadanie zbadanie, czy w 1953 r. grupy polityczne były objęte zakresem międzynarodowej definicji zbrodni ludobójstwa, jak i to, czy skarżący mógł przewidzieć, że jego uczestnictwo w operacji, która doprowadziła do śmierci dwóch partyzantów, mogło zostać w ten sposób zakwalifikowane ${ }^{83}$. Twierdząca odpowiedź

79 Ibidem, pkt 238.

80 Ibidem.

81 Kononov p. Łotwie, pkt 236.

82 Ibidem, pkt 239, 244. Krytyczną ocenę stanowiska większości wyrazili sędziowie Costy, Kalaydjevy oraz Poalelungi, których zdaniem w 1944 r. nie istniały wyraźne podstawy do skazania Kononova za czyny, których się dopuścił, ergo w omawianej sprawie niespełnione zostały wymogi określające istotę zasady legalizmu i doszło do naruszenia art. 7 EKPC. Por. Kononov p. Łotwie, zdanie odrębne sędziego Costy wraz z sędziami Kalaydjievą oraz Poalelungi.

83 Vasiliauskas p. Litwie, pkt 162. 
na oba pytania uzasadniałaby skazanie Vytautasa Vasiliauskasa przez sąd litewski ponad 50 lat później ${ }^{84}$.

Europejski Trybunał Praw Człowieka nie miał wątpliwości co do spełnienia wymogu dostępności kryminalizacji, za czym przemawiała normatywizacja zbrodni ludobójstwa w 1948 r. w postaci przyjętej wówczas konwencji ${ }^{85}$, wyraźnych odniesień do zbrodni ludobójstwa w innych aktach prawnych, a także wciąż relatywnie skąpym w 1953 r. międzynarodowym orzecznictwie sądowym ${ }^{86}$. Trybunał rozpoczął analizę od identyfikacji potencjalnych podstaw odpowiedzialności za zbrodnię ludobójstwa popełnioną na grupie politycznej. Mimo że zbrodnia ta była czynem zabronionym przez prawo traktatowe i zwyczajowe w 1953 r., ani jedno, ani drugie źródło prawa międzynarodowego nie przewidywało jednak ochrony grup politycznych ${ }^{87}$. Przyjęte post factum krajowe przepisy wprowadzające kryminalizację zbrodni ludobójstwa mogły zatem stanowić podstawę odpowiedzialności karnej za tę zbrodnię tylko w takim zakresie, w jakim odpowiadało to międzynarodowej definicji zbrodni ludobójstwa. Rozszerzenie zakresu kryminalizacji na poziomie krajowym - na przykład poprzez ochronę grup politycznych - jest oczywiście dopuszczalne; niedopuszczalne jest natomiast wsteczne egzekwowanie naruszenia takiego szerszego unormowania krajowego pod osłoną prawa międzynarodowego ${ }^{88}$. W sprawie Vasiliauskas nieistotne

${ }^{84}$ Litwa stała się stroną Konwencji w sprawie zapobiegania i karania zbrodni ludobójstwa w 1992 r. W 1998 r. do litewskiego kodeksu karnego wprowadzono art. 71, który jako jedną z chronionych grup wymienia także grupę polityczną. Nowy kodeks karny z 2003 r. także odnosi się do grup politycznych (art. 99). Por. Vasiliauskas p. Litwie, pkt 29-53.

${ }_{85}$ Konwencja w sprawie zapobiegania i karania zbrodni ludobójstwa, uchwalona przez Zgromadzenie Ogólne Narodów Zjednoczonych 9 grudnia 1948 r. (ratyfikowana zgodnie z ustawą z 18 lipca 1950 r.); Dz. U. z 1952 r. Nr 2, poz. 9.

${ }^{86}$ Vasiliauskas p. Litwie, pkt 167-168.

87 Jednak w odniesieniu do prawa zwyczajowego Trybunał odnotował, że nie jest jasne, czy rozszerza ono zakres prawa traktatowego. W konsekwencji zawężająca konkluzja została zaaprobowana przez ETPC w związku z czytelnym i jednostajnym ograniczeniem zakresu ludobójstwa w definicjach traktatowych. Por. Vasiliauskas p. Litwie, pkt 175, 178.

88 Ibidem, pkt 181. 
było więc to, czy wnioskodawca mógł w ogóle przewidzieć kryminalizację określonych zachowań wymierzonych w grupy chronione jako zbrodnię ludobójstwa, skoro zaatakowanie grupy politycznej nie stanowiło wówczas takiej zbrodni. W rezultacie Trybunał stwierdził, że doszło do naruszenia art. $7 \mathrm{EKPC}^{89}$.

Omówione pokrótce orzeczenia ETPC wykazują normatywną złożoność towarzyszącą analizie, czy skazujący za popełnienie zbrodni międzynarodowych sąd krajowy nie narusza zarazem standardu nullum crimen sine lege. Warto przy tym podkreślić, że mimo iż Trybunał $z$ istoty posiadanego mandatu nie podejmuje weryfikacji prawidłowości postępowania dowodowego prowadzonego przed sądami krajowymi, $\mathrm{w}$ sprawach $\mathrm{z}$ art. 7 EKPC przeprowadza on jednak analizę nie tylko tego, czy kryminalność określonego typu zbrodni międzynarodowej była dostępna i przewidywalna w chwili jego popełnienia, ale i tego, czy przeprowadzona przez sąd krajowy subsumpcja czynu pod typ zbrodni, biorąc pod uwagę jej definicję w chwili czynu, była w danej sprawie właściwa ${ }^{90}$. Omówione w tej części sprawy wykazują ponadto szczególną problematyczność następczego ścigania przestępstw w oparciu o podstawy normatywne wywodzone przez sądy krajowe z prawa międzynarodowego czy to ze względu na niewłaściwą kategoryzację czynów (Korbely), czy też ze względu na brak stosownej podstawy karalności w prawie międzynarodowym (Vasiliauskas). Z kolei metody dookreślania typów czynów karalnych na podstawie prawa międzynarodowego (Kononov) przybierają niekiedy postać identyfikacji pierwiastków bezprawności w złożonym i zróżnicowanym materiale normatywnym obejmującym zarówno prawo wewnętrzne, jak i prawo międzynarodowe.

Mimo usilnych starań ubrania tych rozumowań w gorset obowiązujących przepisów, trudno jest czasami nie odnieść wrażenia, że przewidywalność karalności pewnych zachowań jako zbrodni międzynarodowych, przynajmniej na początkowym etapie rozwoju międzynarodowego prawa karnego, w większej mierze opierała się na niemoralnym ich charakterze aniżeli na konkretnych podstawach

$89 \quad$ Ibidem, pkt 186, 191.

90 Kononov p. Łotwie, pkt 187, 191, 197-198. 
normatywnych oraz rzeczywistej zdolności poznania treści norm przez potencjalnego sprawcę, zwłaszcza mając na względzie nadzwyczajny charakter i kontekst tych naruszeń. Prawdopodobnie najlepszym tego przykładem są konflikty zbrojne charakteryzujące się przecież odmienną od tej obowiązującej w czasach pokoju specyfiką zakazów i zezwoleń. Do jakiego stopnia moralna dostępność komunikatu kryminalizacyjnego jest w stanie zrekompensować braki dostępności formalnej w takich nadzwyczajnych sytuacjach i stanach, pozostaje wciąż niejasne ${ }^{91}$. Niezaprzeczalne jest jednak to, że tzw. argument z dostępności moralnej pełnił na przestrzeni lat ważną funkcję legitymizującą orzecznictwo międzynarodowych i krajowych sądów w sprawach dotyczących zbrodni międzynarodowych w związku z gwarancjami określonymi przez zasadę legalizmu.

\section{Podsumowanie}

Wymagana siła uzasadnienia, przewidywalności i dostępności nie jest - ani w etyce, ani w prawie - jednolita dla każdego typu zachowania. Przeciwnie, jest ona w dużej mierze zależna od tego, jakie zachowanie ma być odtąd uznawane za zabronione i karalne. Kryminalizacja zabójstwa czy zgwałcenia jest traktowana jako naturalna i pożądana, ponieważ zachowania te przynależą do kategorii malum in se. Tekstowa dostępność kryminalizacyjnego komunikatu zdaje się w tych przypadkach mniej istotna, aniżeli ma to miejsce w odniesieniu do zachowań o mniejszym kwantum abstrakcyjnie ujmowanej karygodności przynależących do kategorii malum prohibitum.

Zgodzić należy się z tego względu z opinią przywołanego już wcześniej Lona L. Fullera, który zauważył, że „potrzeba tej edukacji [prawnej P.G.] będzie, co jasne, uzależniona od tego, jak daleko wymogi prawne odstępują od podzielanych poglądów na dobro i zło"92. Tak postrzegany

${ }^{91}$ Por. H. Frowe, The Ethics of War and Peace. An Introduction, London-New York 2016, s. 41-49.

92 L. Fuller, op. cit., s. 50. 
element moralny decyzji kryminalizacyjnej uzasadnia rozluźnienie rygorów składających się na formalną przewidywalność normy karnej. Skoro określone zachowanie jest powszechnie uznawane za naganne, trudno zaakceptować twierdzenie, że nie wiedziało się o tym, iż może być ono także zakazane przez przepisy prawa. Argument ten znajduje prawdopodobnie najbardziej wyraziste odbicie w międzynarodowym prawie karnym, począwszy od wydanego przez trybunał norymberski wyroku aż po współczesne procesy toczące się przed sądami międzynarodowymi i krajowymi.

Zbrodnie międzynarodowe, nawet jeśli nie wszystkie, przynależą do kategorii malum in se. Fakt ten stanowi silne uzasadnienie mniej formalistycznego podejścia do analizy spełnienia poszczególnych gwarancji związanych z zasadą legalizmu. W czasach, gdy multiplikacja ośrodków stanowienia i interpretacji norm karnoprawnych, jak i lawinowo wzrastająca liczba zakazów karnoprawnych wyznaczają stałą dynamiką otaczającej nas rzeczywistości normatywnej, międzynarodowe prawo karne pozostaje tym systemem, w odniesieniu do którego zarzuty o naruszenie legalizmu są zwyczajnie mniej przekonujące. Dzieje się tak właśnie ze względu na silny pierwiastek moralny wyznaczający kierunek kryminalizacji międzynarodowej.

Wbrew normatywistycznemu ujęciu, należy przyjąć, że komunikat kryminalizacyjny jest nie tylko komunikatem prawnym, lecz także komunikatem moralnym. To, czy świadomość bezprawności podejmowanych działań sprawcy zbrodni międzynarodowych będą wywodzić z jednego czy drugiego źródła, powinno być traktowane jako kwestia poboczna. Ważne jest zaś to, aby zasada legalizmu oraz inne gwarancje były interpretowane w sposób uniemożliwiający sprawcom zbrodni międzynarodowych wykorzystywanie ich jako przydatnej zasłony prawnej celem uzasadnienia własnych czynów prowadzących do szerokiej wiktymizacji na podstawie merytorycznie wątpliwych twierdzeń, że przewidzieć ich karalnego charakteru nie byli w stanie.

Niezależnie od wykazanych problemów związanych z aplikacją zasady legalizmu do międzynarodowych procesów karnych, trendy rozwojowe $\mathrm{w}$ obrębie międzynarodowego prawa karnego, czy to $\mathrm{z}$ racji akceptacji wyższych standardów w postępowaniu przed pierwszym 
stałym trybunałem międzynarodowym (art. 77 Statutu MTK), czy też w konsekwencji narastania dookreślającej znamiona poszczególnych zakazów karnych praktyki orzeczniczej, pozwala na stwierdzenie, że w przyszłości standardy gwarancyjne nullum crimen, nulla poena sine lege najprawdopodobniej opierać się będą w dominującym zakresie na dostępności prawnej, nie zaś (wyłącznie) na dostępności moralnej komunikatu kryminalizacyjnego. Zmiana ta nie będzie jednak symbolizowała postępującej „nadkryminalizacji międzynarodowej” prowadzącej do rozmijania się warstwy prawnej i etycznej. Przeciwnie, będzie ona oznaką dojrzałości i rozwoju systemu międzynarodowego prawa karnego.

\section{'Nullum CRIMEN, NULla POENA SINE LEGE'}

A ZBRODNIE MIĘDZYNARODOWE

\section{Streszczenie}

Artykuł ma na celu podjęcie problemu moralnej dostępności prawa $\mathrm{w}$ zestawieniu ze standardem nullum crimen, nulla poena sine lege możliwym do wywiedzenia z orzecznictwa Europejskiego Trybunału Praw Człowieka oraz pomocniczo także innych sądów i trybunałów w sprawach dotyczących przewidywalności bezprawnego i karalnego charakteru czynów składających się na zbrodnie międzynarodowe. Dwa pytania wyznaczają zakres prowadzonych analiz. Po pierwsze, analizie poddane zostaje to, do jakiego stopnia karalność zbrodni międzynarodowych była i jest przewidywalna dla zwykłego adresata normy karnoprawnej. Po drugie zaś, artykuł podejmuje kwestię, w jakim zakresie uzasadnione jest powoływanie się na argument $\mathrm{z}$ tzw. dostępności moralnej komunikatu kryminalizacyjnego w celu zrekompensowania pewnych niedociągnięć formalnych charakterystycznych dla legislacji międzynarodowej. Badane są ponadto poszczególne kryteria zasady legalizmu w zestawieniu ze zbrodniami międzynarodowymi. Szerszemu omówieniu poddano także trzy rozpatrywane przez ETPC sprawy (Kononov, Vasiliauskas oraz Korbely) odnoszące się kolejno do zbrodni wojennych, zbrodni ludobójstwa oraz zbrodni przeciwko ludzkości. 


\section{'Nullum CRIMEN, NULla POENA SINE LEGE' AND INTERNATIONAL CRIMES}

\section{Summary}

The aim of this article is to address the problem of the moral availability of the law in relation to the standard nullum crimen, nulla poena sine lege, which may be derived from the case law of the European Court of Human Rights and other courts and tribunals in cases concerning the predictability of the unlawful and punishable nature of acts constituting an international crime. Two questions determine the scope of this inquiry. First, I examine to what extent the punishability of international crimes has met the predictability criterion as far as the ordinary addressee of a provision of criminal law is concerned. Secondly, the article raises the question of the extent to which it is justified to rely on an argument on the grounds of the "moral availability" of criminalization to compensate for certain formal shortcomings characteristic of international legislation. In addition, I examine particular criteria of the principle of legality in relation to international crimes. In this respect, I discuss three cases heard by the ECHR (Kononov, Vasiliauskas and Korbely) concerning war crimes, the crime of genocide, and crimes against humanity respectively.

Słowa kluczowe: zasada legalizmu; międzynarodowe prawo karne; Europejski Trybunał Praw Człowieka; Europejska Konwencja Praw Człowieka.

Keywords: the principle of legality; international criminal law; the European Court of Human Rights; the European Convention on $\mathrm{Hu}$ man Rights.

\section{Literatura}

Амвоs K., 'Nulla Poena Sine Lege' in International Criminal Law, [w:] Sentencing and Sanctioning in Supranational Criminal Law, eds. R. Haveman, O. Olusanya, Antwerp-Oxford 2006, s. 17-36.

Amoury Combs N., Seeking Inconsistency: Advancing Pluralism in International Criminal Sentencing, «The Yale Journal of International Law» 41/2016, s. 1-49.

ArajÄrvi N., ET AL., Cassese's International Criminal Law, Oxford 2013. 
Chiao V., Criminal Law in the Age of the Administrative State, Oxford 2018. DE SAlvia M., Compendium de la CEDH: les principes directeurs de la jurisprudence relative à la Convention européenne des droits de l'homme, Strasbourg 2003.

Frowe H., The Ethics of War and Peace. An Introduction, London-New York 2016.

Fuller L., The Morality of Law, New Haven 1969.

Gallant K.S., The Principle of Legality in International and Comparative Criminal Law, Cambridge 2008.

GARDNer J., The Twilight of Legality, «Australasian Journal of Legal Philosophy» 43/2018, s. 1-16.

Gardner J., Offences and Defences. Selected Essays in the Philosophy of Criminal Law, Oxford 2007.

Hofmański P., Art. 7, [w:] Konwencja o ochronie praw człowieka i podstawowych wolności, I: Komentarz do artykułów 1-18, red. L. GARLICKI, Warszawa 2010 [Legalis].

Husak D., Overcriminalization. The Limits of the Criminal Law, Oxford 2008. JAIN N., Comparative International Law at the ICTY: The General Principles Experiment, "American Journal of International Law» 109.3/2015, s. 486-497.

Krzan B., Obowiazywanie zasady 'nulla poena sine lege' $z$ perspektywy międzynarodowych trybunałów karnych, [w:] Prawo międzynarodowe. Idee a rzeczywistość, red. E. CAEA-WACINKIEWICZ.

RAImondo F.O., General principles of law in the decisions of international criminal courts and tribunals, Amsterdam 2007.

Sweeney J.A., The European Court of Human Rights in the Post-Cold War Era: Universality in Transition, Abingdon 2013.

Szczucki K., Dostępność moralna czy językowa? Rzecz o wykładni prokonstytucyjnej prawa karnego, [w:] 'Nullum crimen sine lege', red. I. SEPIOŁO, Warszawa 2012, s. 43-56.

Thorburn M., Criminal law as public law, [w:] Philosophical Foundations of Criminal Law, eds. A. Duff, S.P. Green, Oxford 2011, s. 21-43.

Timmerman M., Legality in Europe. On the principle nullum crimen, nulla poena sine lege in EU law and under the ECHR, Cambridge-Antwerp-Portland 2018.

Tomuschat C., The Nuremberg Legacy, «Journal of International Criminal Justice» 4/2006, s. 830-844.

Werle G., Jessberger F., Principles of International Criminal Law, Oxford 2014.

ZAPPALÀ S., Human Rights in International Criminal Procedure, Oxford 2003. 